\title{
PENGEMBANGAN TRADITIONAL GAME PARK DENGAN KONSEP ARSITEKTUR NEO VERNAKULAR DI DESA SUNYALANGU, BANYUMAS
}

\author{
Novia Rahmawati \\ Program Studi Arsitektur, Fakultas Teknik, Universitas Wijayakusuma Purwokerto \\ rahmawatinovia396@gmail.com \\ Yohana Nursruwening \\ Program Studi Arsitektur, Fakultas Teknik, Universitas Wijayakusuma Purwokerto \\ yohanakober@gmail.com \\ Wita Widyandini \\ Program Studi Arsitektur, Fakultas Teknik, Universitas Wijayakusuma Purwokerto \\ witawidyandini@yahoo.co.id
}

\begin{abstract}
Abstrak
Banyumas merupakan salah satu kabupaten di Jawa Tengah yang memanfaatkan potensi sumber daya alam dan lingkungan sekitar sebagai dasar pembangunan pariwisatanya. Salah satu objek wisata yang memanfaatkan potensi tersebut adalah Taman Brilian Angkruk Logawa yang berada di Desa Sunyalangu, Kecamatan Karanglewas. Dalam merancang Traditional Game Park ini, permainan tradisional anak khas Banyumasan, yaitu Panggal, menjadi konsep dasar dalam perancangannya. Keunikan tema yang ditawarkan oleh Taman Brilian Angkruk Logawa serta adanya peningkatan pengunjung yang cukup signifikan, menjadi dasar dilakukannya penelitian tentang "Pengembangan Traditional Game Park Dengan Konsep NeoVernakular di Desa Sunyalangu, Banyumas". Metode penelitian yang digunakan adalah metode kualitatif, dengan pengumpulan data melalui 3 cara, yaitu : observasi langsung, wawancara, dan dokumentasi. Data tersebut kemudian dianalisa secara mendalam dengan menggunakan metode deskriptif. Hasil dari penelitian ini berupa perencanaan dan perancangan Traditional Game Park dengan konsep Arsitektur Neo Vernakular di Desa Sunyalangu, Kecamatan Karanglewas, Kabupaten Banyumas, yang meliputi : konsep tata lahan, konsep bentuk bangunan, dan konsep interior bangunan.
\end{abstract}

Kata kunci : neo-vernakular, permainan tradisional, wisata

\begin{abstract}
Banyumas is one of the regency in Central Java that utilizes the potential of natural resources and the surrounding environment as the basis for tourism development. One of the tourist attraction that take advantage of this potential is "Brilian Angkruk Logawa Park" located in Sunyalangu, Karanglewas. In designing the Traditional Game Park, Banyumasan children's traditional game, namely Panggal, is the basic concept in the design. The uniqueness of the theme offered by the Brilian Angkruk Logawa Park and a significant increase in visitors, became the basis for a research on "Development of Traditional Game Park with Neo-Vernacular Concept in Sunyalangu, Banyumas". The research method used is a qualitative method, with data collection in 3 ways, namely : direct observation, interviews, and documentation. Then, the data is analyzed using descriptive methods. The results of this research were the planning and design of the Traditional Game Park with the concept of Neo Vernacular Architecture in Sunyalangu, Karanglewas, Banyumas, which includes : land use concepts, building form concepts, and building interior concepts.
\end{abstract}

Keywords : neo-vernacular, tour, traditional games 


\section{PENDAHULUAN}

Pariwisata dikembangkan tidak hanya untuk bertujuan meningkatkan perolehan devisa bagi negara saja, namun juga pariwisata diharapkan dapat berperan sebagai katalisator pembangunan. Dilihat dari sudut ekonomi, pengembangan pariwisata memiliki beberapa keuntungan diantaranya kesempatan kerja bertambah, meningkatkan penerimaan pajak, meningkatkan nilai tambah produk hasil kebudayaan. Sehingga tidak mengherankan apabila banyak daerah yang berusaha untuk mengembangkan sektor pariwisatanya. Salah satunya adalah Kabupaten Banyumas. Seiring dengan perkembangan, Kabupaten Banyumas memanfaatkan sumber daya alam yang ada dengan mengadakan pembangunan di sektor pariwisata. Salah satu objek wisata yang baru dibuka pada tahun 2019 adalah Taman Brilian Angkruk Logawa.

Taman Brilian Angkruk Logawa berada di Desa Sunyalangu, Kecamatan Karanglewas. Jarak dari pusat kota Purwokerto $\pm 11 \mathrm{~km}$ dengan akses yang mudah dijangkau menggunakan kendaraan pribadi. Kecamatan Banyumas memiliki luas wilayah 132.758 ha yang terdiri dari lahan pertanian dan pemukiman. Taman permainan tradisional yang berada di Kecamatan Karanglewas merupakan dataran tinggi dengan ketinggian topografi 300 600 di atas permukaan air laut (dpl) dengan kemiringan lahan sekitar $8->25 \%$. Curah hujan rata-rata adalah $2.700 \mathrm{~mm}$ pertahun dengan suhu udara rata-rata $32^{\circ} \mathrm{C}$.

Pembangunan Taman Brilian Angkruk
Logawa yang berada di Desa Sunyalangu merupakan hasil kerjasama dari beberapa lembaga seperti Lembaga Masyarakat Desa Hutan (LMDH), Karang Taruna, dan Badan Usaha Milik Desa (Bumdes) dengan dana yang dikumpulkan dari iuran warga dan bantuan dari beberapa instansi sebesar Rp 100.000.000,00. Taman ini berada di tepi Sungai Logawa dan diresmikan secara langsung oleh Gubernur Jawa Tengah Ganjar Pranowo dan Bupati Banyumas Ahmad Husein pada hari Kamis, 17 Januari 2019.

Obyek wisata Taman Brilian Angkruk Logawa memiliki daya tarik bagi wisatawan domestik karena memiliki konsep untuk menyelamatkan kebudayaan daerah dan mengedukasi masyarakat untuk lebih mengenal permainan tradisional. Hal itu kemudian dikombinasikan dengan pemandangan alam yang masih alami sehingga menambah kesan zaman dahulu. Adanya Taman Brilian Angkruk Logawa ini diharapkan mampu menghidupkan kembali permainan tradisional yang sekarang mulai tergantikan oleh permainan yang lebih modern.

Sebagai objek wisata yang baru dibuka, taman ini mengalami kenaikan jumlah yang signifikan yaitu sebesar 62,4\%. Berdasarkan wawancara dengan Bapak Deni, salah satu pengelola Taman Brilian Angkruk Logawa diperoleh data pengunjung sebagai berikut : 


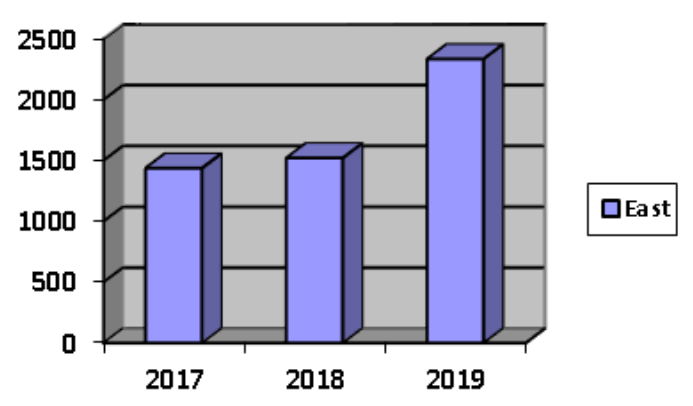

Gambar 1. Grafik Jumlah Pengunjung

(Sumber : Wawancara dengan Bapak Deni, 2020)

Untuk menghasilkan suatu produk pengembangan yang baik, perlu dilakukan studi tentang proyeksi dalam kurun waktu beberapa tahun ke depan dengan harapan kawasan yang dikembangkan menunjukan sesuatu yang signifikan. Dalam menentukan proyeksi jumlah pengunjung dalam kurun waktu 5 tahun mendatang menggunakan rumus :

$$
\begin{aligned}
& \mathrm{Pn}=\mathrm{Po}+\mathrm{h}(\mathrm{r}) \\
& \mathrm{Pn}=\text { Jumlah pengunjung tahun proyeksi } \\
& \mathrm{Po}=\text { Jumlah pengunjung tahun dasar } \\
& \mathrm{r} \quad=\text { Rata-rata pertambahan pengunjung/ } \\
& \text { tahun (dianggap konstan) } \\
& \mathrm{h} \quad=\text { Tahun proyeksi }
\end{aligned}
$$

Perhitungan pengunjung di Taman Brilian Angkruk Logawa pada tahun 2024 sebagai berikut :

$$
\begin{aligned}
& \text { Po }=2335 \\
& \mathrm{r} \quad=827 \\
& \mathrm{~h}=5 \\
& \text { Maka, Pn }=2335+5(827) \\
& =6.470 \text { jiwa }
\end{aligned}
$$

Objek wisata Taman Brilian Angkruk Logawa selalu berupaya meningkatkan kualitas kawasan dengan mengadakan pembangunan, pemeliharaan, dan perbaikan sarana prasarana penunjang wisata. Hal ini bertujuan agar jumlah wisatawan yang berkunjung ke objek wisata Taman Brilian Angkruk Logawa semakin meningkat.

Keunikan tema yang ditawarkan oleh Taman Brilian Angkruk Logawa serta adanya peningkatan pengunjung yang cukup signifikan, menjadi dasar bagi penulis untuk melakukan penelitian tentang "Pengembangan Traditional Game Park Dengan Konsep Neo-Vernakular di Desa Sunyalangu, Banyumas".

\section{METODE PENELITIAN}

Penelitian ini membahas tentang fenomena yang terjadi di Traditional Game Park Taman Brilian Angkruk Logawa, sehingga metode penelitian yang digunakan adalah metode kualitatif. Metode kualitatif ini bertujuan untuk mendapatkan informasi lebih mendalam mengenai Traditional Game Park di Desa Sunyalangu, Banyumas.

Metode pengumpulan data pada penelitian kualitatif dilakukan melalui tiga cara, yaitu : observasi langsung, wawancara mendalam, dan pemanfaatan dokumen (Patton, 2009 : 1). Observasi langsung dilakukan dengan melakukan survei atau pengamatan langsung ke Taman Brilian Angkruk Logawa, wawancara mendalam dilakukan dengan melakukan wawancara dengan pengurus dan warga setempat, sedangkan dokumentasi dilakukan dengan melakukan foto, pengukuran, dan penggambaran site plan dan tampak Taman Brilian Angkruk Logawa. 
Data yang terkumpul tersebut kemudian dianalisa lebih mendalam dengan menggunakan metode deskriptif. Pembahasan dilakukan dengan menganalisa objek apa adanya dengan dokumen-dokumen pendukung. Hasil analisa ini nantinya menjadi dasar bagi penulis pada saat membuat rencana dan rancangan desain Traditional Game Park dengan konsep Arsitektur Neo Vernakuler di Desa Sunyalangu, Banyumas.

Analisa yang dilakukan meliputi Analisa Site dan Analisa Ruang. Dari hasil analisa ini kemudian dibuat zoning, gubahan massa, dan ide bentuk. Setelah itu baru dibuat desain atau gambar kerjanya yang meliputi site plan, denah, tampak, potongan, dan perspektif bangunan

\section{HASIL DAN PEMBAHASAN}

A. LOKASI SITE

Site atau tapak berada di Jl. Raya Baseh, Desa Sunyalangu, Kecamatan Karanglewas, Kabupaten Banyumas.

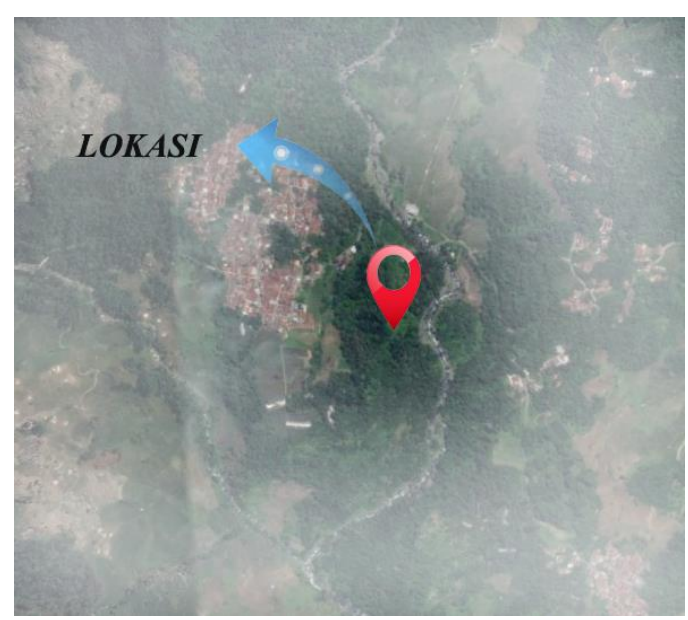

Gambar 2. Peta Lokasi Site Perencanaan (Sumber : Google Earth, 2020

Luas site perencanaan $\pm 10,45 \mathrm{Ha}$, untuk batas-batas site antara lain :

- Sebelah Utara : Hutan, pertanian
- $\quad$ Sebelah Selatan : Pemukiman, hutan

- $\quad$ Sebelah Timur: Sungai Logawa

- $\quad$ Sebelah Barat : Pertanian, permukiman

\section{B. KEMIRINGAN SITE}

Site berada pada ketinggian $342 \mathrm{~m}$, tiap garis kontur berbeda ketinggian $5 \mathrm{~m}$. Penambahan/pengurangan ketinggian yaitu sekitar 74,5 m - 145 m, kelandaian maksimal $17,2 \%-37,6 \%$, dan kelandaian rata-rata 4,9\% $-7,6 \%$.

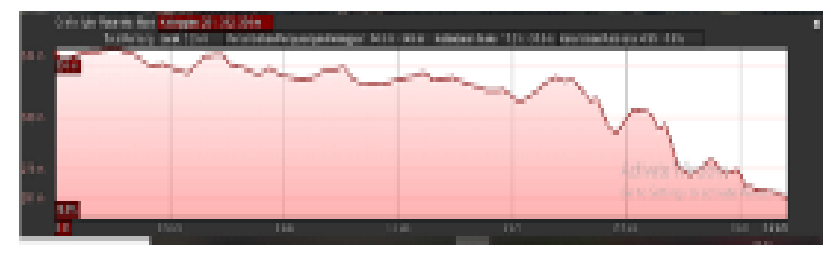

Gambar 3. Kemiringan Site (Sumber : Google Earth, 2020)

\section{PERATURAN BANGUNAN SETEMPAT}

1. Garis Sempadan Sungai

Berdasarkan Perda Kabupaten Banyumas No. 10 tahun 2011 Pasal 28 Ayat 3 dijelaskan bahwa ruang sepanjang tepian sungai besar tidak bertanggul di luar kawasan permukiman dengan lebar minimal 100 (seratus) m dari tepi sungai.

\section{2. $\mathrm{KDB}$}

KDB (Koefisien Dasar Bangunan) adalah rasio perbandingan antara luas lantai dasar bangunan dengan luas lahan (Zulkaidi, 2016: 10). Berdasarkan Perda Kabupaten Banyumas No 3 tahun 2011 Pasal 29, dijelaskan bahwa bangunan dengan fungsi sosial budaya dapat dibangun dengan KDB paling tinggi $60 \%$. 


\section{ANALISA SITE}

\section{Analisa Sirkulasi dan Pencapaian}

Menurut Hakim (2018:196), suatu rasa emosional seseorang bisa dihasilkan dari perpaduan antara kecepatan gerak dengan sifat pergerakan terhadap suatu objek, sehingga dalam merancang sirkulasi harus diperhatikan dengan hati-hati. Kriteria sirkulasi untuk Tradisional Game Park ini, antara lain nyaman untuk beraktifitas para pengunjung, aman dari bahaya dan gangguan, efektif dan tidak berbelitbelit, serta adanya perbedaan sirkulasi bagi kendaraan dan pejalan kaki untuk memberikan kenyamanan dan keamanan bagi pengunjung.

Dengan melihat kriteria sirkulasi di atas, maka setelah dilakukan analisa, diperolehlah konsep tentang sirkulasi bagi kendaraan dan pejalan kaki, sebagai berikut :

a. Jalur kendaraan dibuat memutar satu arah pada kawasan wisata untuk efektifitas.

b. Jalur kendaraan masuk dari arah Utara dan keluar dari arah Barat.

c. Lokasi saat ini belum memiliki pedestrian, sehingga perlu dibuatkan jalur pedestrian bagi pejalan kaki supaya mereka merasa nyaman dan aman.

d. Pedestrian yang dibuat harus saling berhubungan pada setiap zona, untuk memudahkan pengunjung.

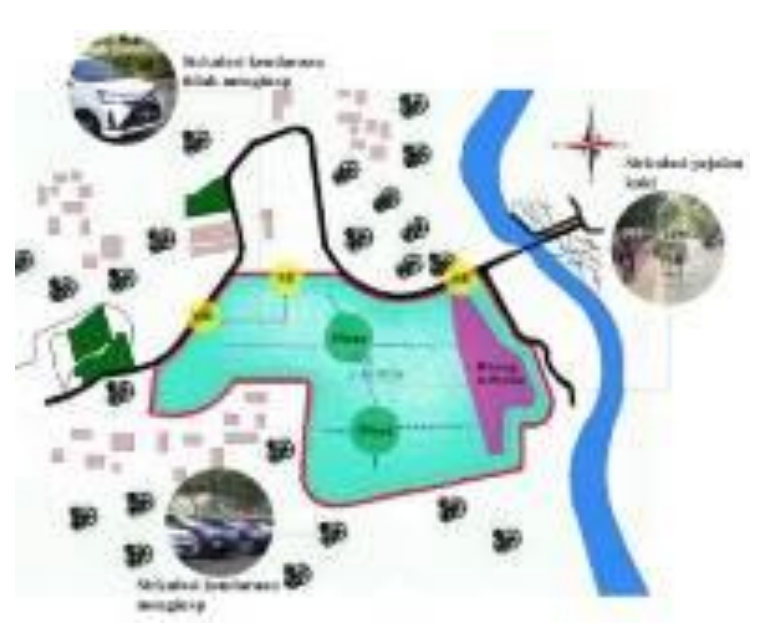

Garis biru : Jalur Kendaraan Garis Jingga : Jalur Pendestrian

Gambar 4. Analisa Sirkulasi (Sumber : Analisa Penulis, 2020)

Jalur kendaraan menggunakan sirkulasi linier dengan satu arah dan dalam hal ini membuat rekayasa jalan, karena penggunaan jalan sebelumnya menuju ke pertanian warga. Sedangkan untuk sirkulasi pendestrian menggunakan sirkulasi radial yang menggunakan ruang terbuka sebagai pusatnya dan berkembang ke segala arah.

\section{Analisa Kebisingan}

Tanaman dapat digunakan sebagai penyerap suara kebisingan untuk daerah yang membutuhkan ketenangan (Hakim (2018: 214). Selain dengan meletakan vegetasi di sekitar tapak, untuk meredam kebisingan dapat dilakukan dengan memberikan bidang-bidang masif pada bagian yang yang menghadap ke sumber bising, serta dengan menggunakan ruang- ruang penyangga pada daerah sumber bising seperti ruang publik atau ruang service yang tidak memerlukan ketenangan.

\section{Analisa Klimatologi}

Pada perancangannya secara lansekap, untuk area terbuka vegetasi akan digunakan untuk peneduh bagi pengunjung dari sinar matahari, 
sedangkan untuk bangunan akan menggunakan sun filter shading agar terhindar dari silau dan panas matahari.

Lokasi objek wisata yang berada berada di pegunungan sehingga terjadi angin gunung dan angin lembah yang bertiup dari lembah menuju puncak gunung, terjadi pada siang hari. Sebaliknya, angin yang bertiup dari gunung menuju lembah merupakan angin gunung, terjadi pada malam hari. Untuk mengatasinya bisa dilakukan dengan menanam pohon, membuat dinding masif, dan membuat massa bangunan untuk membelokkan angin.

Karena lokasi objek wisata yang berada di pegunungan, maka sering terjadi hujan. Air hujan dimanfaatkan untuk kebutuhan akan sumber air mengingat adanya musim kemarau. Beberapa cara yang dilakukan untuk menangani hujan antara lain membuat tandon ataupun resapan untuk air hujan, penggunaan material yang tahan terhadap air hujan, dan penanaman pohon untuk mengurangi percepatan turunnya air hujan.

\section{Analisa Zonifikasi}

Untuk membuat nyaman sebuah ruang, maka perlu adanya zonifikasi ruang sesuai dengan jenis atau kelompoknya. Pertimbangan yang menjadi dasar perencanaan zonifikasi, antara lain jenis kegiatan yang beragam, tingkat pencapaian, dan faktor kenyamanan ruang.

Konsep yang muncul pada perancangan Traditional Game Park setelah dianalisa zonafikasinya adalah sebagai berikut:

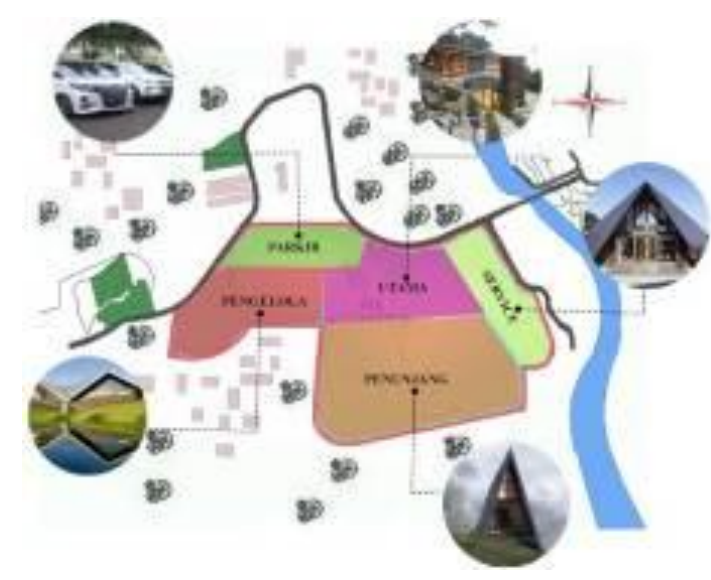

Gambar 5. Analisa Zonifikasi (Sumber : Analisa Penulis, 2020)

\section{Analisa View}

View menghadap ke arah Timur yang merupakan pemandangan Sungai Logawa yang dapat dilihat dari ketinggian bukit. Selain itu, view lainnya yang dapat dinikmati keindahannya yaitu menghadap ke arah Utara dan Selatan yang berupa hutan.

\section{E. IDE DESAIN}

Menurut Hurlock dalam Zakariya (1998: 325), permainan tradisional adalah bentuk kegiatan permainan yang berkembang dari suatu kebiasaan masyarakat tertentu. Apabila jumlah hubungan sosial bertambah, maka permainan anak kualitasnya pun menjadi lebih sosial. Traditional Game Park merupakan tempat rekreasi yang memiliki fungsi hiburan sekaligus fungsi edukasi yang melekat pada setiap jenis permainan tersebut.

Untuk objek wisata yang banyak dikunjungi anak-anak, maka menggunakan warna yang full color, karena selain berwisata anak juga dapat belajar warna dan dapat membangkitkan rasa percaya diri anak. Permukaan bahan material menggunakan 2 jenis tekstur yaitu keras dan 
kasar untuk fasilitas umum, seperti paving, cor beton, aspal. Sedangkan untuk fasilitas bermain anak menggunakan material interlock yaitu semacam paving tetapi tidak keras melainkan empuk.

Penggunaan lantai juga perlu memperhatikan pola atau pattern untuk memberikan kesan batasan ruang, menambah nilai estetis dan atraktif, serta memberikan pengarahan kepada suatu objek (Hakim, 2018: 260). Untuk Traditional Game Park terdapat berbagai macam bentuk pola dalam tempat wisata yaitu bentuk persegi, lingkaran, polygon, segitiga, dan gabungan beberapa bentuk dengan tujuan untuk mengajarkan anak mengenal bentuk pola.

Untuk mempermudah dalam proses perancangan, maka konsep dasar tersebut dikembangkan dan dibagi menjadi dua yaitu konsep makro dan konsep mikro.

\section{Konsep makro}

Konsep makro pada perancangan ini adalah menciptakan desain Traditional Game Park sebagai pusat rekreasi dan edukasi, yang di dalamnya terdapat desain tata lahan, bentuk bangunan, dan interior ruang dengan arsitektur Neo-Vernakular, yang merupakan bentuk arsitektur yang mengambil elemen arsitektur setempat (baik elemen fisik maupun non fisik) ke dalam bentuk modern (Sumalyo, 1996 : 452). Jadi arsitektur Neo-Vernakular bertujuan untuk melestarikan unsur-unsur lokal yang terbentuk oleh sebuah tradisi dan kemudian mengalami pembaruan yang lebih modern.

Perancangan Traditional Game Park ini mengambil konsep dari Panggal yaitu salah satu permainan tradisional anak khas Banyumasan yang bentuknya menyerupai gasing tapi terbuat dari kayu. Panggal terdiri dari tiga bagian yaitu kepala, badan, dan kaki. Hal itu dikaitkan dengan unsur bangunan yaitu kepala sebagai atap, badan sebagai dinding, dan kaki sebagai pondasi. Apabila salah satu unsur tersebut hilang, maka bangunan menjadi tidak sempurna. Panggal memiliki karakteristik berputar pada porosnya dengan bagian kaki dijadikan sebagai titik keseimbangan. Perputaran tersebut menggambarkan sirkulasi pengunjung yang di buat melingkar dengan tatanan massa di sekelilingnya sehingga memudahkan akses pengunjung untuk berpindah-pindah secara dinamis. Untuk menambah daya tarik pengunjung serta menghasilkan dokumentasi yang estetis, maka untuk fasade bangunan dan fasilitas penunjang lainnya menggunakan warna yang cerah dan mencolok.

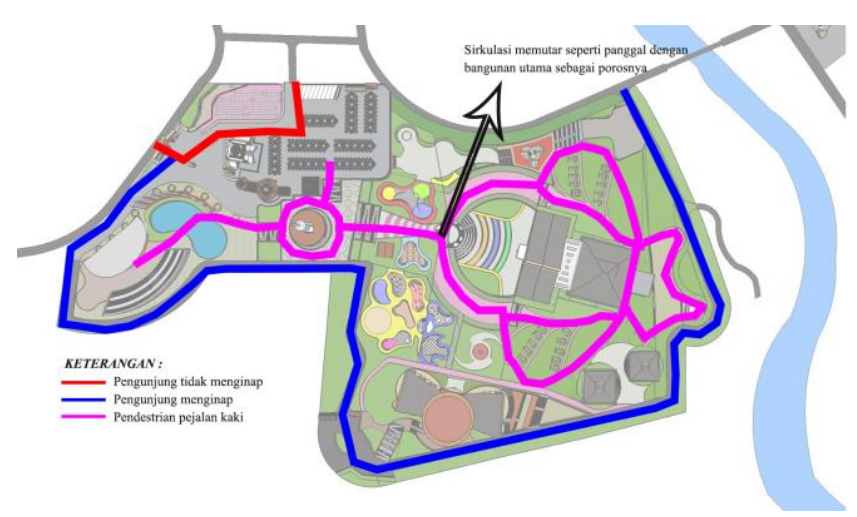

Gambar 6. Sirkulasi dengan Konsep Panggal (Sumber : Dokumentasi Pribadi, 2020)

\section{Konsep Mikro}

a. Konsep Tata Lahan, bertujuan untuk menciptakan desain tatanan lahan yang terbagi dalam beberapa zona yang masing-masing zona mengelilingi sebuah plaza maupun ruang 
terbuka yang digunakan sebagai penghubung antar massa bangunan. Selain plaza, untuk menghubungkan massa bangunan digunakan pergola yang berfungsi sebagai peneduh atau pelindung dari panas dan terik sinar matahari

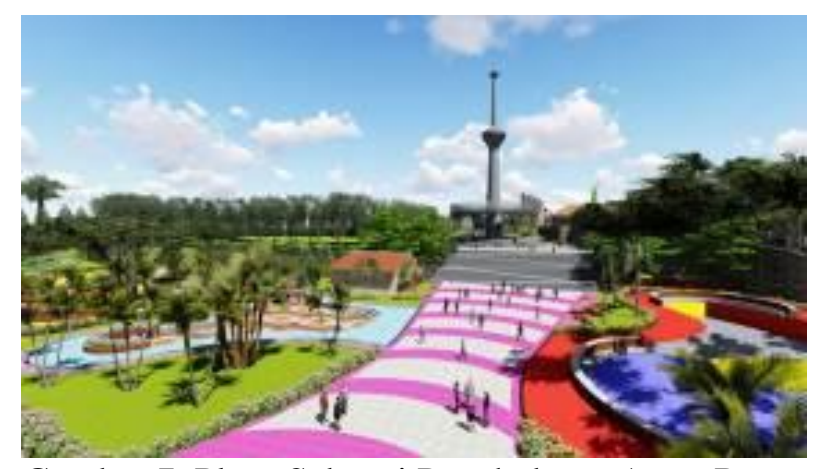

Gambar 7. Plaza Sebagai Penghubung Antar Ruang (Sumber : Dokumentasi Pribadi, 2020)

b. Konsep Bentuk Bangunan, bertujuan menciptakan desain bentuk bangunan dengan konsep atraktif yang diangkat dari kebudayaan sekitar. Ide dasar bentuk bangunan diambil dari bentuk permainan tradisional yang dipadukan dengan beberapa kearifan lokal di sekitar site sebagai penerapan arsitektur Neo-Vernakular.

1. Museum, Taman Permainan Indoor, dan Workshop

Wujud bangunan mengambil konsep dari atap Panggang Pe yang dimodifikasi. Atap dibuat sedikit melengkung untuk penghawaan di dalam museum. Sedangkan taman permainan indoor mengambil bentuk atap Joglo dan dibuat 2 lantai dengan mengikuti kontur tanah.

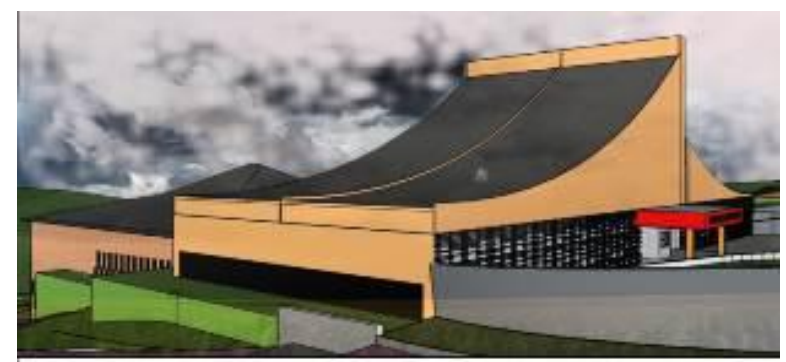

Gambar 8. Museum, Taman Permainan Indoor, Dan Workshop

\section{Foodcourt}

Mengambil konsep terowongan supaya anak ketika sedang makan di dalamnya tidak merasa bosan karena mereka seperti bermain di dalam sebuah terowongan.

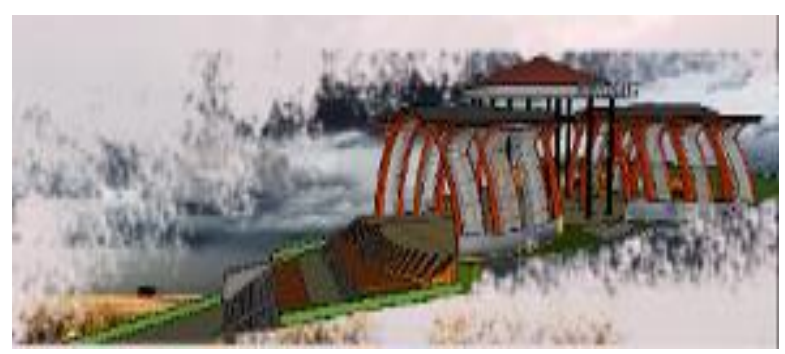

Gambar 9. Foodcourt

(Sumber : Dokumentasi Pribadi, 2020)

\section{Kantor Pengelola}

Ide bentuk yang diambil pada denah kantor pengelola adalah Kudi, yaitu senjata khas Banyumas. Atap menggunakan bentuk Tajug yang dikombinasikan dengan bentuk pelana di sisi kanan dan kirinya.

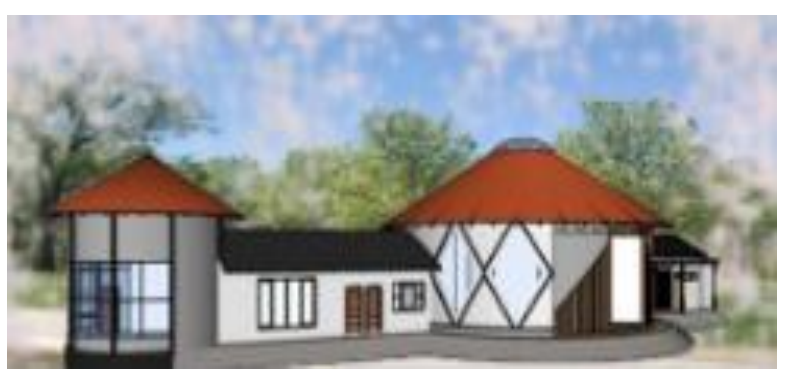

Gambar 10. Kantor Pengelola (Sumber : Dokumentasi Pribadi, 2020)

\section{Penginapan}

Bangunan penginapan dibuat dengan model panggung untuk melindungi dari serangan hewan karena objek wisata berada di wilayah yang masih sangat alami. Atap yang digunakan yaitu atap Pelana yang langsung menutupi seluruh bagian dinding penginapan. 


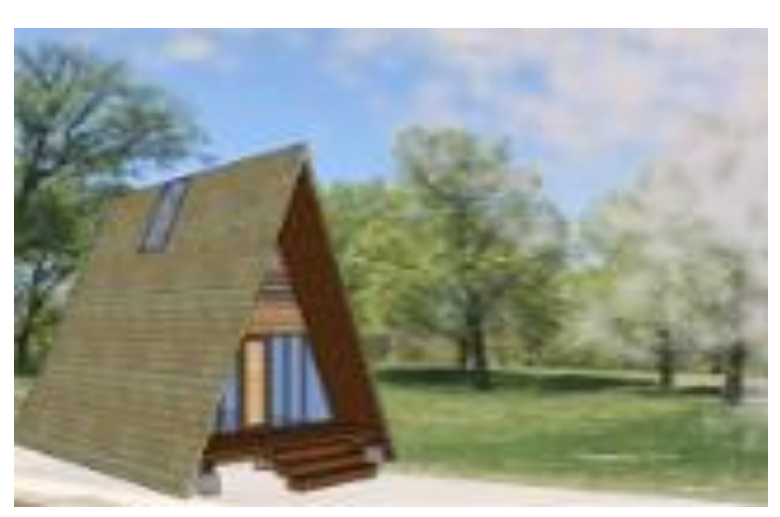

Gambar 11. Penginapan

(Sumber : Dokumentasi Pribadi, 2020)

\section{Tiketing}

Salah satu potensi dari Desa Sunyalangu, adalah Kampung Entok. Bentuk bangunan tiketing terinspirasi dari Entok yang sedang bersatu. Pada bagian atas bangunan terdapat salah satu jenis permainan tradisional yaitu meriam bambu yang membentang.

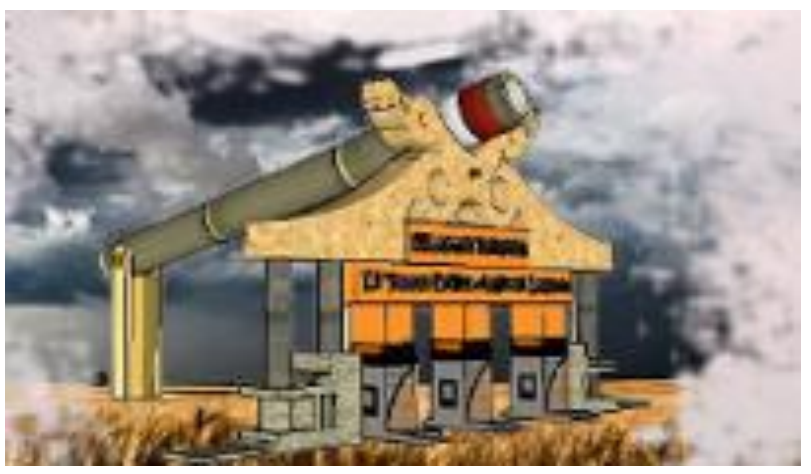

Gambar 12. Tiketing

(Sumber : Dokumentasi Pribadi, 2020)

\section{Masjid}

Kubah pada bangunan masjid dibuat lebih tinggi seperti ditumpu oleh trapesium menggambarkan bahwa ibadah merupakan salah satu bentuk memuliakan Tuhan. Sedangkan dinding pada bagian tempat wudhu dibuat lengkung sebagai wujud ketika seseorang sedang berwudhu sedikit membungkukkan badannya supaya lebih khusyuk, karena wudhu merupakan salah satu bagian terpenting sebelum melakukan kegiatan ibadah.

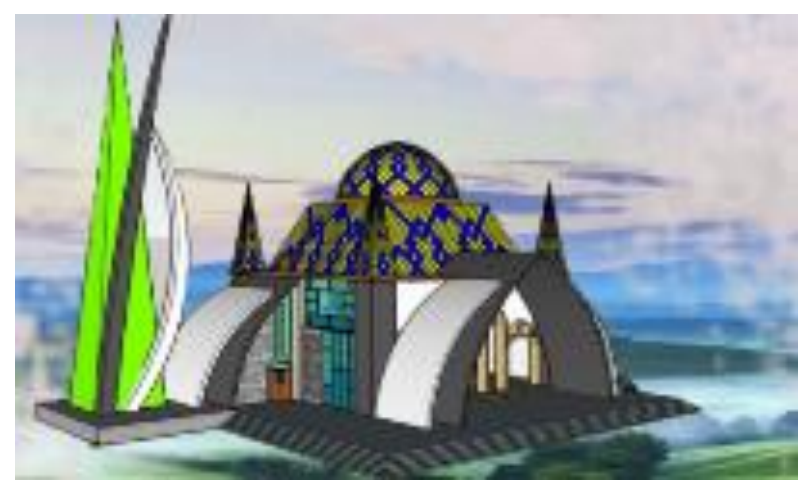

Gambar 13. Masjid

(Sumber : Dokumentasi Pribadi, 2020)

\section{Warung Makan}

Bentuk atap dari warung makan dibuat lengkung bertujuan untuk mengarahkan angin supaya dapat masuk ke dapur dan mengeluarkan udara melalui sela-sela rooster, karena dapur merupakan tempat orang memasak dan udara biasanya berubah menjadi panas.

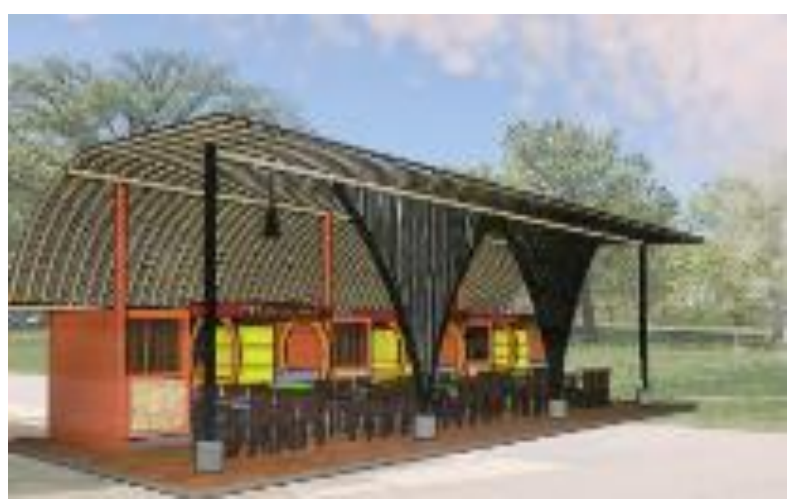

Gambar 14. Warung Makan (Sumber : Dokumentasi Pribadi, 2020)

\section{Amphiteater}

Dengan bentangan yang lebar kurang lebih 60 meter jika terdapat kolom akan sangat mengganggu pandangan penonton dan menyulitkan ruang gerak pertunjukkan. Oleh sebab itu, atap bangunan amphiteater dibuat dengan menggunakan rangka space frame. 


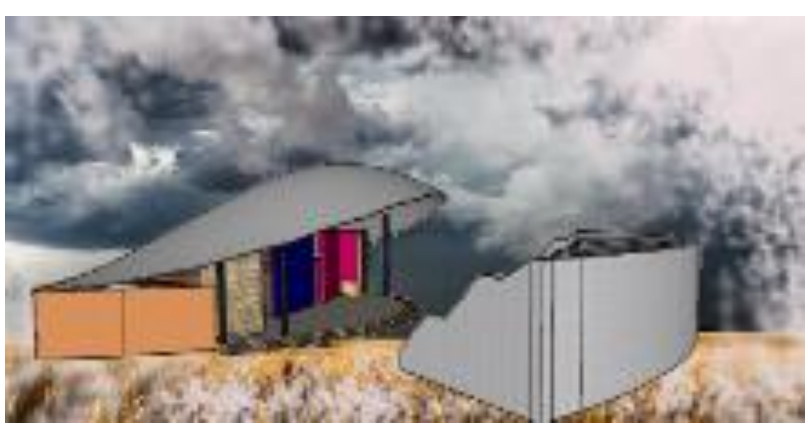

Gambar 15. Amphiteater

(Sumber: Dokumentasi Pribadi, 2020)

c. Konsep Interior Bangunan, mengambil bentuk dari alat mainan yang digunakan dalam permainan tradisional. Contoh penerapannya adalah bentuk sofa yang dibuat seperti dakon dan bekel, sedangkan bentuk mejanya dibuat seperti panggal. Area tempat duduk ini bisa digunakan perorangan maupun berkelompok bersama dengan keluarga.

Untuk area permainan indoor, idenya mengambil suasana hutan yang banyak di sekitar site. Interior ruang dibuat seolah-olah seperti di dalam hutan dengan tumbuhantumbuhan yang menjulang tinggi hingga ke plafon. Untuk mengakomodasi semangat anakanak yang tinggi, maka untuk interior bangunan menggunakan warna-warna yang cerah.

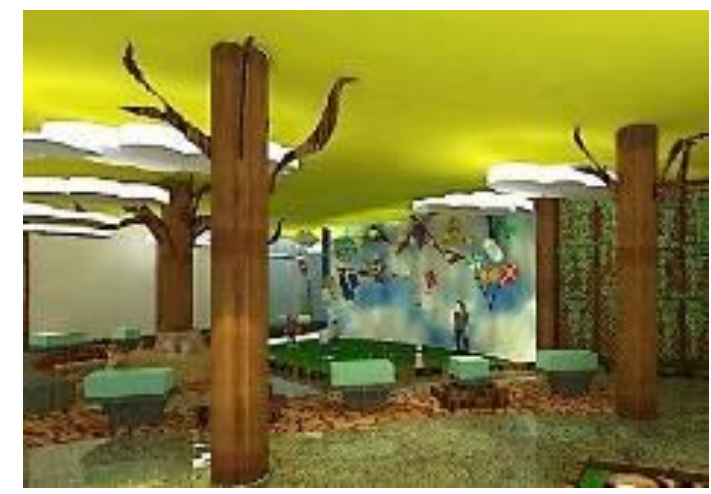

Gambar 16. Interior Permainan Indoor (Sumber : Dokumentasi pribadi, 2020)

\section{KESIMPULAN}

Pengembangan Traditional Game Park di Desa Sunyalangu, Kecamatan Karanglewas, Kabupaten Banyumas ini menggunakan konsep dasar permainan anak khas Banyumasan, yaitu Panggal. Panggal selain melambangkan tiga unsur bangunan yaitu kepala sebagai atap, badan sebagai dinding, dan kaki sebagai pondasi, juga memiliki makna perputaran pada porosnya yang diwujudkan dalam bentuk sirkulasi pengunjung yang melingkar dengan tatanan massa di sekelilingnya sehingga menghasilkan desain tata ruang yang dinamis.

Untuk bentuk bangunannya menerapkan arsitektur Neo-Vernakular dengan mengambil bentuk permainan tradisional serta mengambil beberapa kearifan lokal di sekitar site untuk diaplikasikan pada salah satu atau beberapa unsur bangunan, baik itu fasade bangunan maupun interior dalam bangunan.

\section{UCAPAN TERIMA KASIH}

Penulis mengucapkan terima kasih kepada Program Studi Arsitektur Fakultas Teknik Universitas Wijayakusuma Purwokerto yang telah memfasilitasi penulis sehingga tulisan ini dapat dipublikasikan pada jurnal ilmiah.

\section{DAFTAR PUSTAKA}

Hakim, Rustam., (2018), "Komponen Perancangan Arsitektur Lansekap”, Bumi Aksara, Jakarta.

Patton, Michael Quinn, (2009), "Metode Evaluasi Kualitatif (terjemahan)”, Pustaka Pelajar, Yogyakarta.

Sumalyo, Yulianto, (1996), "Arsitektur Modern Akhir Abad XIX dan Abad XX”, Gadjah Mada University Press, Yogyakarta. 
Zakariya, Rahmad Deky., (1998), "Perencanaan Wisata Permainan Tradisional Anak di Batu”, diakses melalui http://etheses.uin-malang.ac.id/ pada hari Rabu, 26 Februari 2020, pukul 18.04 WIB.

Zulkaidi, Denny. 2016. Teknik Zonasi Dalam Menangani Persoalan Densitas dan Intensitas Pemanfaatan Ruang. Jakarta

Perda Kabupaten Banyumas No 3 tahun 2011 tentang Bangunan Gedung

Perda Kabupaten Banyumas No. 10 tahun 2011 tentang Rencana Tata Ruang Wilayah Kabupaten Banyumas 